\title{
Harita Mühendisleri Özelinde Mühendislik Etiği Ölçeğinin Geçerlilik ve Güvenirlik Analizi Üzerine Bir Çalışma
}

\author{
Şaban INAM1, Halil Burak AKDENİZ ${ }^{1^{*}}$ \\ ${ }^{1}$ Konya Teknik Üniversitesi, Mühendislik ve Doğa Bilimleri Fakültesi, Harita Mühendisliği \\ Bölümü, KONYA \\ * hbakdeniz@ktun.edu.tr
}

\begin{abstract}
Öz: Bu çalışma harita mühendislerinin meslek etiği eğilimlerini belirlemek için oluşturulan mühendislik etiği ölçeğinin geliştirilmesi, geçerlilik ve güvenirliğinin değerlendirilmesi amacıyla planlanmıştır. Bu çalışmanın örneklemini, İç Anadolu bölgesinde görev yapan ve ankete gönüllü olarak katılan 88 harita mühendisi oluşturmuştur. Verilerin analizinde; sayı/yüzde, ölçeğin iç tutarlılık katsayısı, madde toplam puan korelasyon katsayısı, test tekrar test güvenirliliği ve açıklayıcı - doğrulayıcı faktör analizi yöntemleri kullanılmıştır. Mühendislik Etiği Ölçeği, 21 maddeden ve 2 alt ölçekten oluşmaktadır. Kaiser Meyer-Olkin değerinin (0.864) 0.50'nin üstünde olması nedeniyle, örneklem büyüklüğünün faktör analizi yapmaya uygun olduğu anlaşılmıştır. Açıklayıcı faktör analizi sonucunda 2 alt ölçeğin, toplam varyansın \%56.44'ünü açıkladığ bulunmuştur. Tüm ölçeğin Cronbach $\alpha$ güvenirlik katsayısı 0.926 'dır. Madde toplam puan korelasyonları ise 0.182-0.829 arasında değer almaktadır $(\mathrm{p}<0.001)$. Ölçeğin test tekrar test sonuçları 0.859 olarak bulunmuştur. Toplam faktör yükleri hem açıklayıcı hem de doğrulayıcı faktör analizlerinde 0.30 'dan büyük çıkmıştır. Doğrulayıcı faktör analizinde; GFI ile NFI'nın $>0.80$, CFI'nın $>0.90$ ve RMSEA'nın $<0.08$ olduğu bulunmuştur. Ölçeğin yapı geçerliği ile ilgili faktör analizi sonuçları, verilerin modelle uyumlu olduğunu; iki faktörlü yapıyı doğruladığını, ölçeğin madde ve alt boyutlarının ölçekle ilişkili olduğunu, her bir alt boyuttaki maddelerin kendi faktörünü yeterli olarak tanımladığını göstermiştir. Bu çalışma, mühendislik etiği ölçeğinin geçerli ve güvenilir olduğunu göstermiştir. Bu sonuçlar, geliştirilen ölçeğin Türkiye'nin tüm bölgelerinde görev yapan harita mühendisleri ve harita mühendisliği bölümlerinde lisans/lisansüstü öğrenim gören öğrencilerin mesleki etik araştırmalarında başarıyla kullanılabileceğini göstermiştir.
\end{abstract}

Anahtar Kelimeler: Geçerlilik, Güvenirlik, Mühendislik Etiği, Ölçek

\section{A Study on the Validity and Reliability Analysis of Engineering Ethics Scale Specific to Geomatics Engineering}

\footnotetext{
Abstract: The aim of this study is to develop/determine validity and reliability of the Engineering Ethics Scale in order to determine the professional ethical tendencies of geomatics engineers who are active in their profession. The sample of this study consisted of 88 geomatics engineers working in the Central Anatolia region and voluntarily participated in the survey. In the analysis of the data; number / percentage, internal consistency reliability coefficient, corrected item-total correlation, test-retest analysis and explanatoryconfirmatory factor analysis methods were used. The Engineering Ethics Scale consists of 21 items and 2 subscales. As the Kaiser Meyer-Olkin value (0.864) was above 0.50, sample size was found to be suitable for factor analysis. As a result of explanatory factor analysis, it was found that 2 subscales explained $56.44 \%$ of the total variance. The Cronbach Alpha correlation coefficient was found to be 0.926 for the whole scale. The correlation coefficient of the score of each item and the scale score is 0.182 and $0.829(\mathrm{p}<0.001)$. Total factor loads were higher than 0.30 in both explanatory and confirmatory factor analyzes. In confirmatory factor analysis; GFI and NFI were determined to be $>0.80$, CFI was $>0.90$ and RMSEA was $<0.08$. The results of the factor analysis regarding the construct validity of the scale showed that the data confirms consistent with the model, that it confirms two factors, that the items and subscales are related to the scale, and that each subscales identifies its own factor adequately.

This study showed that Engineering Ethics Scale is valid and reliable. These results show that the scale can be used successfully in the professional ethics research related to geomatics engineering department undergraduate / postgraduate students and geomatics engineers.
}

Keywords: Engineering Ethics, Reliability, Scale, Validity 


\section{Giriș}

Etik kavramı toplumsal yaşamın her alanında, günlük işlerimizden tutunda yönetimin en üst kademelerine kadar kullanılmakta olan ve önemsenen bir kavramdır. Toplumsal yaşamın her safhasında karşımıza çıkmakta olan etik kavramı, bir pusula özelliği taşımakta olup yolun ya da rotanın yönlerini belirtmekte; ancak hangi yoldan gidilmesi gerektiği konusunu bireylerin ilgi ve tasarrufuna bırakmaktadır. Amaca erişimde her yolu geçerli sayan günümüz iş yaşamındaki rekabet ortamı, kişisel çıkarlar ve maksimum kar beklentisi çalışanların mesleki etik değerler konusunda sorunlar yaşamasına sebep olmakta; bazen de krize sürüklemektedir. Etik değerlerin ve yargıların dikkate alınmadan yürütüldüğü bir iş hayatının sürdürülebilir olması ve beraberinde getireceği yükün çalışan bireyler tarafından kaldırılabilmesi çok mümkün görünmemektedir. Bu bağlamda, genel etik ve mesleki etik kavramlarının basit ifadeler ile açıklanması, güncel çalışma hayatımızda yer edinmesi ve toplumsal yaşama uyarlanması büyük önem arz etmektedir.

Etik, "bir insanın davranışları sırasında kullandığı ahlaki ilkeler bütünü” olarak tanımlanabileceği gibi, “insanın doğru ile yanlışı ayırt ederken kullandığı kişisel kriterler" olarak da tanımlanabilir (Şaban ve Atalay, 2005).

Mesleki etik, “iş hayatındaki davranışları yönlendiren, onlara rehberlik eden etik prensipler ve standartların toplamına" denilmektedir. Belirli bir meslek grubunun üyelerini yönlendiren, gerektiğinde onları belli kurallar içerisinde davranmaya zorlayan ve gerektiğinde kişisel eğilimlerini sınırlayan, yetersiz ya da ilkesiz üyelerini meslekten dişlayan, mesleki rekabeti düzenleyen ve mesleki ideallerini korumayı amaçlayan mesleki ilkelerdir (Milli Eğitim Bakanlığı, 2006).

$\mathrm{Bu}$ bağlamda, meslek etiğgi; insanların yönetimi, adalet, dürüstlük ve eşitlik konuları ile yakından ilişkili bir kavramdır (Maclagan, 1995). İnsan ilişkilerinin temelinde yer alan değerleri ve özel gruplar için geliştirilmiş belirli davranışları, kuralları ve normları içermektedir (Tansal, 2002). Başka bir ifadeyle meslek etiği, belli bir grup ya da özel bir topluluk için belirlenen, grup ya da özel topluluktaki bireyler tarafindan benimsenen ve inanılan davranış kurallarını kapsamaktadır (Boatright, 2003). Meslek etiği ilkeleri, özellikle personel yönetimi alanındaki uzman ve yöneticilere yol göstermektedir (Maclagan, 1995).

Meslek etiği; saygınlık ve güven kazanmak, ait olunan grubun ilke ve kurallarına uymakla mümkün olur. İcra 
edilen meslekle ilgili belirlenmiş ilke ve kurallara uymak, kurulan mesleki birlik ve çalışma düzeninin devamı için çok önemlidir. Mesleki gereklilikleri yerine getirmek hem kişinin kendine olan güveni kazanmasinı, hem de toplumun meslek mensuplarına karşı güveninin artmasını ve mesleğin yüceltilmesini sağlar. Meslek etiği ilkelerine uygun davranış gösteren meslek mensupları, verdikleri hizmetin doğruluğu ve kalitesi nedeniyle yaptıkları işle ilgili tarafların, meslektaşlarının, devletin ve toplumun güvenini ve saygısını kazanırlar (İşgüden ve Çabuk, 2006).

Mesleki sürdürülebilirlik bakımından önemli bir kavram olan meslek etiği değerine, harita mühendisliği disiplininde ne derece önem verildiğini ölçen geçerli ve güvenilir bir ölçüm aracına ihtiyacın olması, bu çalışmanın temel problemini oluşturmaktadır.

\section{Materyal ve Yöntem}

\subsection{Araştırmanın Amacı}

Araştırma, Mühendislik Etiği Ölçeğinin, geçerlilik ve güvenirliğinin değerlendirilmesi amacıyla metodolojik olarak yapılmıştır.

\section{2. Örnekleme Süreci}

Araştırmanın evrenini, en az lisans derecesi diplomasına sahip harita mühendisleri oluşturmaktadır. Mühendislik Etiği Ölçeği'nin güç analizi için “G-
POWER 3.1 programı" kullanılmıştır. Çalışmadaki regresyon analizi baz alınarak, yordama geçerliliğinde kullanılacak beş değişken göz önünde bulundurulmuş; etki büyüklüğü 0.15 orta- $\% \quad 80$ güç- 0.05 anlamlılık düzeyleri esas alınmıştır. 43 kişiden oluşan örneklem büyüklüğü üzerinden hesaplamalar yapılmıştır. Çalışmadaki değişkenler arası ilişkileri daha net bir şekilde belirtmek için araştırma kapsamında seçilen 145 harita mühendisine "Etik Kuralların Önemsendiği Mesleki Bir Yaşamın Toplum Sağlığı Bakımından Önemi” temalı anket soruları e-mail adreslerine gönderilmiş, anketi gönüllülük esasına göre cevaplamaları istenmiştir. Araştırmada, ankete katılmayı kabul eden ve ölçekleri tam dolduran 88 harita mühendisinin verisi kullanılmıştır.

\subsection{Veri Toplama Araçları}

Çalışmada veriler; "Demografik Veri Toplama Formu" ve "Mühendislik Etiği Ölçeği”" ile toplanmıştır. Araştırma anketi, 10.10.2019 ve 10.12.2019 tarihleri arasında dijital ortamda uygulanmıştır. Çalışmaya katılan harita mühendislerden dijital ortamda onama alınmıştır. Demografik Veri Toplama Formu, çalışmaya katılacak mühendislerin sosyo-demografik özellikleri, cinsiyeti, yaşı, eğitim durumu, çalışma alanı ve mesleki kıdemine ilişkin 5 maddeden oluşmaktadır. Mühendislik Etiği Ölçeği oluşturulurken, literatür taraması sürecinde farklı meslek disiplinlerine uygulanmış etik kavramına 
ilişkin ölçekler ve çalışmalar da incelenmiştir. Yapılan incelemeler sonucunda taslak ölçek formu 30 soru olarak oluşturulmuş, alanında belirlenen 3 uzmandan görüşler alınmış ve bu uzman önerileri doğrultusunda madde sayısı 21'e indirilmiştir. Oluşturulan bu 21 maddelik ölçek, beşli likert türüne " $1=$ Tamamıla Etik, 2=Kısmen Etik, 3=Kararsızım, 4=Kısmen Etik Dışı, 5=Tamamıyla Etik Dışı” göre puanlanmıştır. 21 maddeden oluşan ölçekte alınabilecek toplam puan 21105 puan arasında değişiklik göstermektedir. Ölçekten alınan puan arttıkça, mühendislik etiğine yönelik olumlu tutum da artmaktadır. Ölçeğin 9, 13, 14, 18, 19, 20, 21, 22 ve 23. maddeleri ters olarak puanlanmaktadır.

\subsection{Verilerin Değerlendirilmesi}

Araştırma verilerinin analizinde SPSS 22 ve AMOS 26 paket programları kullanılmıştır. Verilerin değerlendirilmesin de hata (yanılma) payı $\mathrm{p}=0.05$ olarak alınmıştır. Verilerin analizinde;

- tanımlayıcı istatistikler için yüzdelik ve ortalama,

- verilerin güvenirliliğini sınama, ölçek ve alt boyutların iç tutarlılığını belirlemek için Cronbach Alfa Katsayısı,

- ölçek ve alt boyutların madde toplam puan analizi için Pearson Korelasyon Analizi,

- zamana göre değişmezlik bağımlı gruplarda t testi ve Pearson Korelasyon Analizi,
- verilerin geçerliliğini sınamak ve maddefaktör ilişkisinin belirlenmesi için Açıklayıcı Faktör Analizi,

- maddeler ve alt boyutlara ait ölçeğin özgün yapısını karşılayıp karşılamadığını belirlemek için Doğrulayıc1 Faktör Analizi,

- ölçeğin faktörleri arasındaki ilişkinin belirlenmesi için Pearson korelasyon analizi kullanılmıştır.

\section{Bulgular}

Mühendislik Etiği Ölçeğinin, geçerlik ve güvenirliğinin değerlendirilmesi amacıyla yapılan çalışmada ulaşılan sonuçlar üç başlık altında verilmiştir:

1. Sosyodemografik verilere ilişkin sonuçlar,

2. Ölçeğin güvenirlik analiz sonuçları,

3. Ölçeğin geçerlik analiz sonuçları.

Aşağıdaki tabloda araştırmaya katılan harita mühendislerinin cinsiyet, yaş, eğitim durumu, çalışma alanı ve mesleki kıdemine ilişkin demografik verilere göre frekans ve yüzde dağılımları verilmiştir. Toplam 145 harita mühendisi örnekleme alınmıştır. Bu mühendislerin 88 'i araştırmaya katılmış ve ölçek formlarını tam olarak doldurmuştur. Araştırma, ölçek formlarını tam dolduran 88 mühendise ait veriler esas alınarak değerlendirilmiştir. 


\subsection{Demografik Veriler}

Tablo 1. Demografik Değişkenler $(n=88)$

\begin{tabular}{|c|c|c|c|}
\hline \multirow{3}{*}{ Cinsiyetiniz } & & Frekans (n) & Oran $(\%)$ \\
\hline & $\square$ Kadın & 20 & 22.7 \\
\hline & $\square$ Erkek & 68 & 77.3 \\
\hline \multirow[t]{5}{*}{ Yaşınız } & $\square 21-30$ & 26 & 29.5 \\
\hline & $\square 31-40$ & 20 & 22.7 \\
\hline & $\square 41-50$ & 24 & 27.3 \\
\hline & $\square 51-60$ & 12 & 13.6 \\
\hline & $\square 61$ ve üzeri & 6 & 6.8 \\
\hline \multirow[t]{3}{*}{ Eğitim Durumunuz } & $\square$ Lisans & 55 & 62.5 \\
\hline & $\square$ Yüksek Lisans & 18 & 20.5 \\
\hline & $\square$ Doktora & 15 & 17.0 \\
\hline \multirow[t]{3}{*}{ Sektörünüz } & $\square$ Kamu & 26 & 29.5 \\
\hline & $\square$ Özel & 56 & 63.6 \\
\hline & $\square$ Çalışmıyorum & 6 & 6.8 \\
\hline \multirow[t]{5}{*}{ Mesleki Kıdeminiz } & $\square 0-5 \mathrm{y} 1 \mathrm{l}$ & 21 & 23.9 \\
\hline & $\square 6-10 \mathrm{y} 11$ & 18 & 20.5 \\
\hline & $\square 11-15$ y1l & 2 & 2.3 \\
\hline & $\square 16-21$ y1l & 14 & 15.9 \\
\hline & $\square 21$ yıl ve üstü & 33 & 37.5 \\
\hline TOPLAM & & 88 & $\% 100$ \\
\hline
\end{tabular}

Tablo 1'e göre araștırmaya katılanların \%77.3'ü erkek, \%22.7'si ise kadındır. 2017 yılında yayımlanan TMMOB-Harita ve Kadastro Mühendisleri Odası (HKMO) üye verilerine göre aktif üye sayısının \%84.2'si erkek, \%15.8'i kadındır. Bu verilere göre ankete katılımın, cinsiyet yüzdeleri “çalışmanın güvenirliği açısından dengeli ve uygun" olduğu görülmektedir.

\subsection{Güvenilirlik}

Mühendislik Etiği Ölçeği'nin güvenirlik analizinde;

- ölçeğin iç tutarlılığını ölçmek için Cronbach $\alpha$ Güvenirlik Katsayısı

- madde güvenirliliğini ölçmek için Madde-Toplam Puan Analizi,
- $\quad$ ölçeğin değişmezlik özelliğini ölçmek için ise Test-Tekrar Test Yöntemi kullanılmıştır.

\subsubsection{Cronbach alfa analizi}

Harita mühendisliğinde 'etik değerler' algısını oluşturan 21 maddenin tümü analize tabi tutulmuştur. Ölçeğin cronbach alfa katsayısı 0.926 olarak hesaplanmıştır. Hesaplanan $\quad \alpha=0.926^{\prime}$ lik güvenirlik katsayısı, ölçeği oluşturan istatistik tutum maddeleri arasında 'yüksek düzeyde bir iç tutarlılık' olduğunu ifade etmektedir. Verilen cevapların standart sapmas $1=13.258$ ve ortalamas $1=91.65$ olarak bulunmuştur. Bireysel sorumluluklar alt boyutu güvenirlik katsayıs1 $\quad \alpha=0.942 \quad$ ve toplumsal 
sorumluluklar alt boyutu güvenirlik katsayısı $\quad \alpha=0.701 \quad$ olarak hesaplanmıştır.

Tablo 2. Mühendislik etiği ölçeğinin ve alt boyutlarının cronbach alfa güvenirlik katsayıları $(n=88)$

\begin{tabular}{|l|c|c|c|c|}
\hline \multicolumn{1}{|c|}{ Ölçek ve Alt Boyutları } & $\begin{array}{c}\text { Madde } \\
\text { Sayısı }\end{array}$ & $\begin{array}{c}\text { Alınabilecek } \\
\text { Alt-Üst } \\
\text { Puanlar }\end{array}$ & X \pm SS & $\begin{array}{c}\text { Cronbach Alfa } \\
\text { Güvenirlik } \\
\text { Katsayısı }\end{array}$ \\
\hline Mühendislik Etiği Ölçeği & 21 Madde & $21-105$ & $91.65 \pm 13.258$ & 0.926 \\
\hline $\begin{array}{l}\text { Bireysel Sorumluluklar Alt Boyutu } \\
\text { (1.2.3.4.5.6.7.8.9.10.11.12.13.14.15.20.21. } \\
\text { Maddeler) }\end{array}$ & 17 Madde & $17-85$ & $72.93 \pm 12.710$ & 0.940 \\
\hline $\begin{array}{l}\text { Toplumsal Sorumluluklar Alt } \\
\text { Boyutu(16.17.18.19. Maddeler) }\end{array}$ & 4 Madde & $4-20$ & $18.72 \pm 2.095$ & 0.709 \\
\hline
\end{tabular}

\subsubsection{Madde-toplam puan korelasyon analizi}

Tablo 3. Mühendislik etiği ölçeğinin madde-alt boyut puan korelasyonları (n=88)

\begin{tabular}{|c|c|c|c|}
\hline Maddeler & $\mathbf{X} \pm \mathbf{S S}$ & $\begin{array}{l}\text { Madde } \\
\text { Toplam } \\
\text { Korelasyonu }\end{array}$ & $\begin{array}{c}\text { Madde Silme } \\
\text { Güvenirlik } \\
\text { Katsayısı }\end{array}$ \\
\hline $\begin{array}{l}\text { 1-) Mühendisin, geçerli mazereti olmadan iş saatlerini ihlal etmesi (öğle } \\
\text { tatilini uzatma, geç gelme, erken ayrılma) }\end{array}$ & $4.27 \pm 1.142$ & 0.618 & 0.922 \\
\hline $\begin{array}{l}\text { 2-) Mühendisin, meslektaşları ile ilgili gizli bilgi-belgeleri yasal veya } \\
\text { mesleki amaçlarca gerekli olmadığı halde açıklaması }\end{array}$ & $4.56 \pm 0.957$ & 0.742 & 0.920 \\
\hline 3-) Mühendisin, çalışma saatleri içerisinde kişisel işleriyle ilgilenmesi & $3.72 \pm 1.203$ & 0.578 & 0.923 \\
\hline $\begin{array}{l}\text { 4-) Mühendisin, herhangi bir meslektaşı hakkında sosyal çevresinde olumlu- } \\
\text { olumsuz açıklamalarda bulunması }\end{array}$ & $4.02 \pm 1.213$ & 0.526 & 0.925 \\
\hline $\begin{array}{l}\text { 5-) Mühendisin, meslektaşlarına karşı konuşmalarında devamlı üstünlük } \\
\text { sağlamaya çalışması }\end{array}$ & $4.28 \pm 0.922$ & 0.537 & 0.924 \\
\hline $\begin{array}{l}\text { 6-) Mühendisin, işverene veya yöneticiye meslektaşı hakkında devamlı } \\
\text { olarak olumsuz görüşlerde bulunması }\end{array}$ & $4.48 \pm 0.884$ & 0.727 & 0.920 \\
\hline $\begin{array}{l}\text { 7-) Mühendisin, çalışan arkadaşlarını korumak için yöneticilere yalan } \\
\text { beyanda bulunması }\end{array}$ & $4.11 \pm 1.033$ & 0.660 & 0.921 \\
\hline 8-) Mühendisin, çalışanlar arasında cinsiyet ve yaş ayrımı yapması & $4.35 \pm 1.135$ & 0.659 & 0.921 \\
\hline $\begin{array}{l}\text { 9-) Mühendisin, mesleki çalışanları arasında karşıllılı güven, saygı ve } \\
\text { sorumluluğu ön planda tutması }\end{array}$ & $4.92 \pm 0.312$ & 0.340 & 0.927 \\
\hline $\begin{array}{l}\text { 10-) Mühendisin, kurumda çalışanlar arasında din, dil, ırk, hemşericilik } \\
\text { duygusu, düşünce, fikir, siyasal tercihlerine göre ayrım yapması }\end{array}$ & $4.59 \pm 0.990$ & 0.767 & 0.919 \\
\hline $\begin{array}{l}\text { 11-) Mühendisin, "iş ahlâkı ve sosyal sorumluluktan önce para/kazanç gelir", } \\
\text { anlayış1 içerisinde hareket etmesi }\end{array}$ & $4.25 \pm 1.206$ & 0.743 & 0.919 \\
\hline $\begin{array}{l}\text { 12-) Mühendisin, mesleki yaşamında iş ahlakına ve sosyal sorumluluk } \\
\text { ilkesine aykırı davranışlarda bulunması }\end{array}$ & $4.57 \pm 1.003$ & 0.811 & 0.918 \\
\hline 13-) Mühendisin, amacı ne olursa olsun kurum içi bilgileri dışarı sızdırması & $4.47 \pm 1.050$ & 0.829 & 0.918 \\
\hline $\begin{array}{l}\text { 14-) Mühendisin, çalışma arkadaşları arasında "beyaz yalan" anlamında } \\
\text { gerçeği saklaması yada yanlış beyanda bulunması }\end{array}$ & $3.88 \pm 1.015$ & 0.689 & 0.921 \\
\hline $\begin{array}{l}\text { 15-) Mühendisin, "global rekabetin kaçınılmaz ve zamanın çok değerli } \\
\text { olduğu" kabulu içerisinde iş yaşamında ahlaki değerlerle (sorumluluk, } \\
\text { dürüstlük vb.) hareket etmesinin rekabet avantajını kaybettireceğine inanması }\end{array}$ & $3.77 \pm 1.229$ & 0.606 & 0.923 \\
\hline $\begin{array}{l}\text { 16-) Harita Kadastro Mühendisleri Odasının, iş ahlakı konusunda örnek } \\
\text { davranışlarda bulunan üyelerini ödüllendirmesi }\end{array}$ & $4.35 \pm 1.040$ & 0.182 & 0.931 \\
\hline $\begin{array}{l}\text { 17-) Harita Kadastro Mühendisleri Odasının, üyelerini meslek etiği ve } \\
\text { meslek ahlakı konusunda periyodik olarak bilgilendirmesi ve sicil tutması }\end{array}$ & $4.52 \pm 0.857$ & 0.235 & 0.929 \\
\hline $\begin{array}{l}\text { 18-) Mühendisin, mesleki faaliyetlerini ilgili yasalar ve mesleki standartlara } \\
\text { uygun olarak yerine getirmesi }\end{array}$ & $4.90 \pm 0.430$ & 0.213 & 0.928 \\
\hline $\begin{array}{l}\text { 19-) Mühendisin, mesleki çalışanların sosyal güvenlik ve iş hukuku haklarına } \\
\text { önem vermesi }\end{array}$ & $4.94 \pm 0.233$ & 0.313 & 0.927 \\
\hline $\begin{array}{l}\text { 20-) Mühendisin, ücret dışında müşterilerinden değerli hediyeler kabul } \\
\text { etmesi }\end{array}$ & $4.30 \pm 1.019$ & 0.703 & 0.920 \\
\hline $\begin{array}{l}\text { 21-) Mühendisin, geçim sıkıntısı ve ekonomik güçlüklerden dolayı yasal } \\
\text { olmayan kazanç yollarına başvurması }\end{array}$ & $4.40 \pm 1.150$ & 0.787 & 0.918 \\
\hline
\end{tabular}


Mühendislik Etiği Ölçeğinin maddetoplam puan korelasyon analizi Tablo 3’te verilmiştir. Güvenirlik analizleri için 21 maddelik ölçeğin madde-toplam puan korelasyonlarına bakıldığında $(\mathrm{n}=88$ olmak üzere), ölçek maddelerinin ölçek toplam puanıyla olan korelasyon katsayıları 0.182-
0.829 arasında dağılım göstermiş̧tir $(\mathrm{p}=$ 0.000). Ölçeğin madde toplam korelasyonun pozitif ve yüksek olması, maddelerin benzer davranışları örneklediğini ve testin iç tutarlığının yüksek olduğunu göstermektedir.

Tablo 4. Mühendislik etiği ölçeğinin alt boyutlarının toplam ölçek puanları ile korelasyonları

\begin{tabular}{|l|c|c|}
\hline Ölçek Alt Boyutları & \multicolumn{2}{|c|}{$\begin{array}{c}\text { Ölçek Toplam Puan ile Alt Boyutlar Puanları } \\
\text { Arasındaki İlişki }\end{array}$} \\
\hline $\begin{array}{l}\text { Faktör 1 Bireysel Sorumluluklar } \\
\text { Alt Boyutu }\end{array}$ & 0.988 & 0.000 \\
\hline $\begin{array}{l}\text { Faktör 2 Toplumsal Sorumluluklar } \\
\text { Alt Boyutu }\end{array}$ & 0.335 & 0.001 \\
\hline
\end{tabular}

Mühendislik Etiği Ölçeğinin alt boyutlarının toplam ölçek puanları ile korelasyonları Tablo 4'te gösterilmiştir. Ölçek alt boyutlarının toplam ölçek puanıyla korelasyonları (Pearson Momentler Çarpımı Korelasyonu) incelendiğinde;

bireysel sorumluluklar alt boyutunun "toplam ölçek ile pozitif yönde, mükemmel düzeyde ve istatistiksel olarak anlamlı" olduğu $(\mathrm{r}=0.998, \mathrm{p}=0.000)$,

- toplumsal sorumluluklar alt boyutunun "toplam ölçek ile korelasyonu pozitif yönde, orta düzeyde ve istatistiksel olarak anlamlı" olduğu $\quad(\mathrm{r}=0.335, \quad \mathrm{p}=0.001)$ görülmüştür.

\subsubsection{Test-tekrar test analizi}

Tablo 5. Mühendislik etiği ölçeği alt boyutlarından alınan test-tekrar test puan ortalamaları ve korelasyonları $(n=30)$.

\begin{tabular}{|c|c|c|cc|cr|}
\hline \multirow{2}{*}{ Ölçek ve Alt Boyutları } & \multicolumn{2}{|c|}{$\begin{array}{c}\text { Mühendislik Etiği Ölçeği Puan } \\
\text { Ortalaması }(\mathrm{n}=30)\end{array}$} & \multicolumn{4}{c|}{ Analiz Sonuçları } \\
\cline { 2 - 7 } & $\begin{array}{c}\text { İlk Uygulama } \\
\mathrm{X} \pm \mathrm{SS}\end{array}$ & $\begin{array}{c}\text { İkinci Uygulama } \\
\mathrm{X} \pm \mathrm{SS}\end{array}$ & $\mathrm{r}$ & $\mathrm{p}$ & $\mathrm{t}$ & $\mathrm{p}$ \\
\hline $\begin{array}{c}\text { Toplam Ölçek } \\
\text { Bireysel Sorumluluklar } \\
\text { Alt Boyutu }\end{array}$ & $76.86 \pm 13.45$ & $94.17 \pm 12.14$ & 0.859 & 0.000 & 1.877 & 0.071 \\
\hline $\begin{array}{c}\text { Toplumsal } \\
\text { Sorumluluklar Alt } \\
\text { Boyutu }\end{array}$ & $17.93 \pm 2.82$ & $18.97 \pm 1.71$ & 0.472 & 0.008 & 2.253 & 0.032 \\
\hline
\end{tabular}

Mühendislik Etiği Ölçeği, harita mühendisleri tarafindan doldurulduktan sonra test-tekrar test güvenirlik analizi için seçilen 30 kişilik gruba aynı test 4 hafta sonra tekrar uygulanmıştır. Ölçeğin testtekrar test güvenirlik katsayıs1, Pearson Momentler Çarpımı Korelasyonu ile 
değerlendirilmiştir. Alt boyutlarından

alınan test-tekrar test puan ortalamaları ve korelasyonları Tablo 5'te gösterilmiştir. Analiz sonucu ölçeğin iki alt boyutunun test-tekrar test puanları arasinda istatistiksel olarak pozitif yönde anlamlı bir ilişki olduğu saptanmıştır ( Toplam Ölçek: $\mathrm{r}=0.859, \mathrm{p}=0.000$; Bireysel Sorumluluklar

Alt Boyutu: $\mathrm{r}=0.900, \quad \mathrm{p}=0.000$;
Toplumsal, Sorumluluklar Alt Boyutu: $\mathrm{r}=0.472, \mathrm{p}=0.008)$.

Ayrica, alt boyutlarında 4 hafta ara ile uygulanan iki ölçüm sonucu elde edilen puan ortalaması arasında anlamlı bir fark olup olmadığını saptamak için bağımlı gruplarda $\mathrm{t}$ testi yapılmış, puan ortalamaları arasında istatistiksel olarak anlamlı fark bulunmamıştır ( $\mathrm{p}>0.05)$.

\subsection{Geçerlilik}

\subsubsection{Açıklayıcı faktör analizi}

Tablo 6. Mühendislik etiği ölçeğinin açıklayıcı faktör analizi sonuçları

\begin{tabular}{|c|c|c|}
\hline Maddeler & $\begin{array}{l}\text { Temel Bileşenler } \\
\text { Analizindeki } \\
\text { Faktör } \\
\text { Yük Değerleri }\end{array}$ & $\begin{array}{l}\text { Faktörlerin } \\
\text { Varyansları } \\
\text { Açılama } \\
\text { Oranı }\end{array}$ \\
\hline \multicolumn{3}{|l|}{ Faktör 1} \\
\hline $\begin{array}{l}\text { 1-) Mühendisin, geçerli mazereti olmadan iş saatlerini ihlal etmesi (öğle } \\
\text { tatilini uzatma, geç gelme, erken ayrılma) }\end{array}$ & 0.679 & \multirow{17}{*}{$\% 43.38$} \\
\hline $\begin{array}{l}\text { 2-) Mühendisin, meslektaşları ile ilgili gizli bilgi-belgeleri yasal veya mesleki } \\
\text { amaçlarca gerekli olmadığı halde açıllaması }\end{array}$ & 0.805 & \\
\hline 3-) Mühendisin, çalışma saatleri içerisinde kişisel işleriyle ilgilenmesi & 0.638 & \\
\hline $\begin{array}{l}\text { 4-) Mühendisin, herhangi bir meslektaşı hakkında sosyal çevresinde olumlu- } \\
\text { olumsuz açıklamalarda bulunması }\end{array}$ & 0.575 & \\
\hline $\begin{array}{l}\text { 5-) Mühendisin, meslektaşlarına karşı konuşmalarında devamlı üstünlük } \\
\text { sağlamaya çalışması }\end{array}$ & 0.604 & \\
\hline $\begin{array}{l}\text { 6-) Mühendisin, işverene veya yöneticiye meslektaşı hakkında devamlı olarak } \\
\text { olumsuz görüsslerde bulunması }\end{array}$ & 0.795 & \\
\hline $\begin{array}{l}\text { 7-) Mühendisin, çalışan arkadaşlarını korumak için yöneticilere yalan beyanda } \\
\text { bulunması }\end{array}$ & 0.717 & \\
\hline 8-) Mühendisin, çalışanlar arasında cinsiyet ve yaş ayrımı yapması & 0.696 & \\
\hline $\begin{array}{l}\text { 9-) Mühendisin, mesleki çalışanları arasında karşılıklı güven, saygı ve } \\
\text { sorumluluğu ön planda tutması }\end{array}$ & 0.355 & \\
\hline $\begin{array}{l}\text { 10-) Mühendisin, kurumda çalışanlar arasında din, dil, ırk, hemşericilik } \\
\text { duygusu, düşünce, fikir, siyasal tercihlerine göre ayrım yapması }\end{array}$ & 0.826 & \\
\hline $\begin{array}{l}\text { 11-) Mühendisin, "iş ahlâkı ve sosyal sorumluluktan önce para/kazanç gelir" } \\
\text { anlayışı içerisinde hareket etmesi }\end{array}$ & 0.773 & \\
\hline $\begin{array}{l}\text { 12-) Mühendisin, mesleki yaşamında iş ahlakına ve sosyal sorumluluk ilkesine } \\
\text { aykırı davranıșlarda bulunması }\end{array}$ & 0.847 & \\
\hline 13-) Mühendisin, amacı ne olursa olsun kurum içi bilgileri dışarı sızdırması & 0.860 & \\
\hline $\begin{array}{l}\text { 14-) Mühendisin, çalışma arkadaşları arasında "beyaz yalan" anlamında } \\
\text { gerçeği saklaması yada yanlış beyanda bulunması }\end{array}$ & 0.728 & \\
\hline $\begin{array}{l}\text { 15-) Mühendisin, "global rekabetin kaçınılmaz ve zamanın çok değerli } \\
\text { olduğu" kabulu içerisinde iş yaşamında ahlaki değerlerle (sorumluluk, } \\
\text { dürüstlük vb.) hareket etmesinin rekabet avantajını kaybettireceğine inanması }\end{array}$ & 0.642 & \\
\hline 20-) Mühendisin, ücret dışında müşterilerinden değerli hediyeler kabul etmesi & 0.749 & \\
\hline $\begin{array}{l}\text { 21-) Mühendisin, geçim sıkıntısı ve ekonomik güçlüklerden dolayı yasal } \\
\text { olmayan kazanç yollarına başvurması }\end{array}$ & 0.830 & \\
\hline \multicolumn{3}{|l|}{ Faktör 2} \\
\hline $\begin{array}{l}\text { 16-) Harita Kadastro Mühendisleri Odasının, iş ahlakı konusunda örnek } \\
\text { davranışlarda bulunan üyelerini ödüllendirmesi }\end{array}$ & 0.738 & \multirow{4}{*}{$\% 13.06$} \\
\hline $\begin{array}{l}\text { 17-) Harita Kadastro Mühendisleri Odasının, üyelerini meslek etiği ve meslek } \\
\text { ahlakı konusunda periyodik olarak bilgilendirmesi ve sicil tutması }\end{array}$ & 0.736 & \\
\hline $\begin{array}{l}\text { 18-) Mühendisin, mesleki faaliyetlerini ilgili yasalar ve mesleki standartlara } \\
\text { uygun olarak yerine getirmesi }\end{array}$ & 0.834 & \\
\hline $\begin{array}{l}\text { 19-) Mühendisin, mesleki çalışanların sosyal güvenlik ve iş hukuku haklarına } \\
\text { önem vermesi }\end{array}$ & 0.596 & \\
\hline
\end{tabular}


Mühendislik Etiği Ölçeğinin geçerliliğini sınamak amacıyla, yap1 geçerliliği analiz yöntemlerinden olan açıklayıcı faktör analizi ve doğrulayıcı faktör analizi uygulanmıştır. Mühendislik Etiği Ölçeği'nin açıklayıcı ve doğrulayıcı faktör analizleri öncesinde Kaiser-MeyerOlkin katsayısı (KMO) 0.864 ve Barlett testi sonucu $1228.389 \quad(\mathrm{p}<0.05)$ olarak tespit edilmiştir. Buna göre varyans-kovaryans matrisinin birim matrisine eşit olmadığı ve ölçek maddelerinin arasında ilişki olduğundan çalışmanın faktör analizine uygun olduğuna karar verilmiştir. $\mathrm{Bu}$ sonuçlara dayanarak, 21 maddeden oluşan Mühendislik Etiği Ölçeği’nin faktör yapısını belirlemek amacıyla açıklayıcı faktör analizi yöntemlerinden temel bileşenler analizi yapılmış ve faktör analizi sonrası toplam varyansın \%56.44'sini açıklayan, öz değeri 1.00 'in üzerinde olan 2 faktörlü yapı Tablo 6' da verilmiştir. Faktör analizinde \%40 ile \%60 arasında değişen varyans oranları ideal olarak kabul edildiği (Scherer, 1988) düşünüldüğünde bu araştırmada elde edilen varyans miktarının yeterli düzeyde olduğu söylenebilir. Bireysel sorumluluklar alt boyutu toplam varyansin \%43.38'ini, toplumsal sorumluluklar alt boyutu toplam varyansın \%13.06'sını açıklamaktadır.

Açıklayıcı faktör analizi sonucunda bireysel sorumluluk alt boyutunun faktör yükleri $0.355-0.860$ arasında, toplumsal sorumluluk alt boyutunun faktör yükleri 0.596-0.834 değerleri arasında olduğu saptanmıştır.

\subsubsection{Doğrulayıcı faktör analizi}

Tablo 7. Araştırmanın uyum iyiliği indeks sonuçları

\begin{tabular}{|c|c|c|c|c|c|c|c|c|c|c|}
\hline & $\mathbf{X}^{\mathbf{2}}$ & $\mathbf{D F}^{\mathbf{a}}$ & $\mathbf{X}^{\mathbf{2}} / \mathbf{D F}$ & $\mathbf{R M S E A}^{\mathbf{b}}$ & $\mathbf{G F I}^{\mathbf{c}}$ & $\mathbf{C F I}^{\mathbf{d}}$ & $\mathbf{I F I}^{\mathbf{e}}$ & $\mathbf{R M R}^{\mathbf{f}}$ & $\mathbf{N F I}^{\mathbf{g}}$ & TLI $^{\mathbf{h}}$ \\
\hline Model & 254.435 & 175 & 1.453 & 0.071 & 0.80 & 0.93 & 0.93 & 0.064 & 0.81 & 0.92 \\
\hline
\end{tabular}

Doğrusal faktör analizi sonucu elde edilen araştırmanın uyum iyiliği indeks sonuçları Tablo 7'de verilmiştir. Çeşitli uyum iyiliği indeksleri önerilmesine rağmen tek bir test veya indeks, modeli doğru olarak tanımlayamaz. Bu nedenle çalışmada örnek büyüklüğünün yeterliliğini gösteren $\left(\mathrm{X}^{2} / \mathrm{df}\right)$ ile uyum ve rekabet indeksleri (RMSEA, GFI, IFI, CFI, NFI, RMR, TLI) kullanılmıştır. $\mathrm{RMSEA}=0.071, \mathrm{GFI}=0.80$, $\mathrm{IFI}=0.93, \mathrm{CFI}=0.93 \mathrm{NFI}=0.81, \mathrm{RFI}=0.77$, TLI= 0.92 olarak bulunmuştur (Tablo 7). 


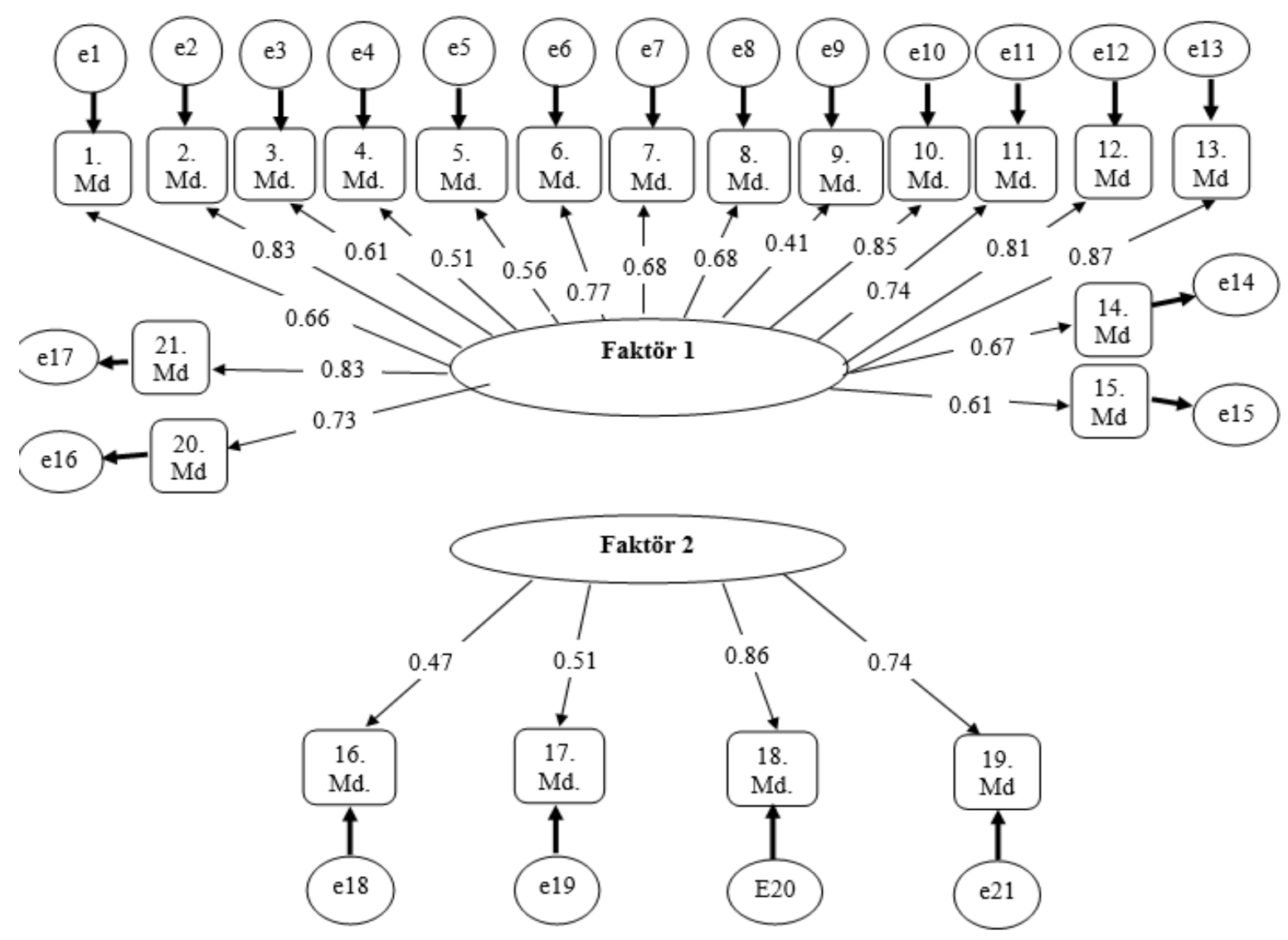

Şekil 1. Mühendislik etiği ölçeğinin doğrulayıcı faktör analizi

Yapısal modelde yer alan tutarlı olup olmadığını ve maddelerin parametreleri gösteren AMOS çıktısı Şekil hipotetik bir değişkeni” ölçüp ölçmediğini 1'de görülmektedir. Doğrulayıcı faktör belirler (Şencan, 2005). Cronbach alfa analizi sonucunda, bireysel sorumluluklar alt katsayısı, ölçekte yer alan $\mathrm{k}$ maddenin boyutunun faktör yükleri 0.41-0.87, varyansları toplamının genel varyansa toplumsal sorumluluklar alt boyutunun oranlanması ile bulunan bir ağırlıklı standart faktör yükleri 0.47-0.86 arasında olduğu değişim ortalamasıdır (Ercan ve Kan, 2004). saptanmıştır.

\section{Tartışma}

Cronbach alfa; Likert türü toplamalı ölçeklerde, anlamsal farklılık ölçeklerinde, Stapel ölçeklerinde, toplam veya ortalama puana dayanan diğer psikometrik testlerde ve bileşik maddelerden oluşan indeks türü ölçüm araçlarında "maddelerin birbirleriyle
Likert tipi derecelendirme ölçeklerinin kullanıldığı araştırmalarda Cronbach alfa katsayısı hesaplanmaktadır. Cronbach alfa katsayısı 0.40'dan küçük ise ölçek güvenilir değil, 0.40-0.59 arası düşük güvenirlikte, 0.60-0.79 arası oldukça güvenilir, 0.80-1.00 arası ise yüksek derecede güvenilir olarak kabul edilir (Akgül, 2005). Bu çalışmada, Mühendislik Etiği ve alt boyut ölçeklerinin 
Cronbach alfa değerleri 0.70 üzerinde bulunmuştur. Elde edilen sonuçlara göre ölçeğin toplam Cronbach alfa değerinin yüksek düzeyde güvenirliliğe sahip olduğu ve alt boyutların Cronbach alfa değerinin ise 0.70'in üstünde güvenilir olduğu belirlenmiştir (Tablo 2).

Madde-toplam puan analizi; ölçek maddelerinden alınan puan ile ölçeğin toplam puanı arasındaki ilişkiyi göstermektedir. Madde-toplam puan korelasyon katsayılarının ortalaması testin güvenilirliğini verir (Şencan, 2005). Madde analizi, bir ölçekte yer alan maddelerin uygulamasından elde edilen sonuçlarının seçilen ölçüte göre işe yarayıp yaramadığını sorgulamayı, işe yaramıyorsa olası nedenlerini anlamayı ve amaca göre gerekli düzeltmeleri yapmamızı sağlar. (Büyüköztürk, 2015). Madde-toplam puan korelasyon değeri genelde en alt sınır olarak 0.20 alınmakta, 0.30-0.40 arasında olan maddelerin "iyi", 0.40 '1n üstünde olan maddelerin "çok iyi" düzeyde ayırt edici ve dolayısıyla güvenilir olduğu belirtilmektedir (Tavşancıl, 2019). Bu araştırmada, 21 maddelik ölçeğin madde-toplam puan korelasyonları incelendiğinde; Mühendislik Etiği Ölçeği maddelerinin korelasyon katsayılarının $0.182 \quad-\quad 0.829$ arasında dağıldığı ve 0.182 değere sahip madde hariç tüm maddeler için istatiksel olarak anlamlı olduğu belirlenmiştir (Tablo 3). 0.182 değere sahip madde üzerinde değişiklik yapılmaması veya ölçekten çıkarılmamasının nedeni; ankete katılan harita mühendislerinin, üyesi olduğu HKMO tarafından “iş ahlakı konusunda örnek davranışlarda bulunan üyelerini ödüllendirmesi ya da onursuz davranışlarda bulunan üyelerine yaptırım uygulaması" konusunda eğilimini ölçmek olmuştur.

Mühendislik Etiği Ölçeği alt boyutlarının toplam ölçek puanıla korelasyonu incelendiğinde, bireysel sorumluluklar alt boyutunun toplam ölçek puanıla korelasyonu 'pozitif' yönde, 'çok iyi' düzeyde ve istatistiksel olarak anlamlı bulunmuştur $(r=0.988, p=0.000)$. Toplumsal sorumluluklar alt boyutunun toplam ölçek puanıla korelasyonu 'pozitif' yönde, 'iyi' düzeyde ve istatistiksel olarak 'anlamlı' bulunmuştur $(\mathrm{r}=0.335, \mathrm{p}=0.001) . \mathrm{Bu}$ sonuçlar, Mühendislik Etiği Ölçeğinin bütün maddelerinin kendi alt boyutunun toplam puanı ile 'yeterli korelasyona sahip' olduğunu ve 0.182 değere sahip madde hariç (sebebi yukarıda açıklanmıştır), madde güvenirliğinin 'yükssek' düzeyde olduğunu göstermiştir ve yeni geliştirilen ölçeğin güvenirliğini kanıtlamıştır (Tablo 4).

Test-tekrar test yöntemi, ölçeğin değişmezlik özelliğini inceleyen ve en çok tercih edilen güvenirlik analizlerindendir. Genellikle Pearson Momentler Çarpımı Korelasyon analiz yöntemi kullanılarak 
değerlendirilir. Bir ölçeğin zamana karş1 değişmez olduğunu belirlemek amaciyla hesaplanan korelasyon katsayısının +1 'e yakınlığı arttıkça, güvenirliği de artmaktadır (Şencan, 2005; Tezbaşaran, 1997). Pearson Momentler Çarpımı Korelasyon katsayısı -1 ile +1 arasında değerler alır. $r=0.00$ ilişki yok, r=0.01-0.29 düşük düzeyde ilişki, $\mathrm{r}=0.30-0.70$ orta düzeyde ilişki, $\mathrm{r}=0.71-0.99$ yüksek düzeyde ilişki, r=1.00 ise mükemmel ilişki olduğu şeklinde yorumlanır (Köklü ve diğ., 2006). Test-tekrar test yönteminde iki ölçüm arasında dört - altı hafta ara olması ve testin en az 30 kişilik bir gruba yapılması önerilmektedir (Tavşancıl, 2019). Testtekrar test karşılaştırmaları sadece korelasyon rakamlarına bakılarak değil, aynı zamanda tanımlayıcı istatistikî analiz sonuçları, birinci ve ikinci test sonuçlarının ortalamaları ve standart sapmaları incelenerek de değerlendirmeye alınır (Şencan, 2005). Bu araştırmada, 30 kişilik gruba anket çalışması 4 hafta ara ile iki defa uygulanmıştır. $\mathrm{Bu}$ tekrarlı iki uygulama arasındaki değişmezlik katsayısı, ölçeğin tamamı için $0.859(\mathrm{p}=0.000)$, bireysel sorumluluklar alt boyutu için 0.900 $(\mathrm{p}=0.000)$, toplumsal sorumluluklar alt boyutu için $0.472 \quad(p=0.008)$ olarak bulunmuştur (Tablo 5). Bu sonuçlar, aynı kişilerin farklı zamanda ölçeğe verdiği yanıtların benzer ve tutarlı olduğunu belirlemiştir.

Test-tekrar test korelasyon katsayısına ek olarak iki ölçüm sonucunda alınan puanların ortalamalarının ve standart sapmalarının değerlendirilmesi önerilir. Her iki ölçüm sonucunun benzer olması gerekir (Ergin, 1995; Şencan, 2005; Tezbaşaran, 1997). Bu doğrultuda anket/ölçek 4 hafta ara ile tekrar uygulanmış, $\mathrm{t}$ testi analizi ile iki ölçüm sonucunda ölçek toplam ve alt boyut puan ortalamaları arasında istatistiksel olarak anlamlı bir fark ortaya çıkmamıştır ( $\mathrm{p}>0.01)$. Bu bulgu, ölçeğin güvenirliliği için bir kanıt daha oluşturmuştur.

Faktör analizi, temel olarak birbiriyle ilişkili değişkenleri belli alt gruplar altında toplamak için kullanılır. Yani, faktör analizinde değişkenler gruplandırılarak ortak faktörlerin oluşturulması amaçlanmaktadır. Eğer ölçek yeni geliştiriliyorsa doğrulayıcı faktör analizi yapmadan önce açıklayıcı faktör analizi yapılmalıdır. $\mathrm{Bu}$ yöntemde açıklayıcı faktör analizine göre belirlenen yöntemler doğrulanır (Harrington, 2009; Şimşek, 2007; Şencan, 2005; Ergin, 1995; Tavşancıl, 2019). Faktör analizleri, cevaplayıcıların geliştirilmekte olan ölçme aracındaki maddelere verdiği tepkiler arasında belli bir düzen olup olmadığını ortaya koymak için kullanılan bir yap1 geçerliği tekniğidir (Tavşancıl, 2019). 
Açıklayıcı Faktör Analizi, değişkenler arasındaki ilişkiyi analiz etmek için kullanılır. Faktör analizi, orijinal veri setinden gerekli bilgileri kaybetmeden çok sayıdaki değişkeni daha az sayıdaki bağımsız değişkene indirgemeyi sağlar (Ahadzie ve ark., 2008).

Faktör analizi için ilk yapılması gereken veri setinin yeterliğinin araştırılmasıdır. Kaiser-Mayer-Olkin (KMO) örneklem yeterliliği testi, faktör analizinin uygulanması için örnek yeterliliğini test etmeyi amaçlar (Ghosh ve Jintanapakanont, 2004). Bartlett'in küresellik testi değeri istatistiksel olarak anlamlı olmalı ve faktör analizi yapmak için KMO değeri en az 0.60 olmalıdır (De Vellis, 2012; Johnson ve Christensen, 2014). Bu çalışmada, KMO katsayısı 0.864 ve Barlett testi sonucu $\mathrm{X}^{2}=1228.389, \mathrm{p}=0.000$ olarak bulunmuştur. $\mathrm{Bu}$ sonuçlar, örneklem sayısının faktör analizleri için yeterli ve varyans-kovaryans matrisinin birim matrisine eşit olmadığı, ölçek maddelerinin arasında ilişki olduğundan çalışmanın faktör analizine uygun olduğunu göstermiştir.

Literatürde faktör yüklerinin toplam varyansı açıklama yüzdesinin 40 ile 60 arasında olması yeterli kabul edilmektedir (Akgül, 2005; Şencan, 2005; Tavşancıl, 2019). Bu çalışmada, açıklayıcı faktör analizi sonucunda öz değeri 1.00'ın üzerinde olan 2 faktörlü yapının ortaya çıktığı saptanmıştır. Faktör 1 (bireysel sorumluluklar) alt boyutunun toplam varyansın \%43.38'ini, Faktör 2 (toplumsal sorumluluklar) alt boyutunun toplam varyansın \%13.06'sını açıklarken, bu iki faktör açıklanması gereken varyansın toplam \%56.44'ünü açıkladığı görülmektedir (Tablo 6). Yapılan bu ölçek geliştirme çalışmasında, Mühendislik Etiği Ölçeği için yeterli düzeyde toplam varyans elde edilmiştir. Mühendislik Etiği Ölçeği maddelerinin alt boyutlarındaki temel bileşenler analizinde faktör yük değerleri orta (0.30-.050) ve yüksek (0.60 ve üzeri) düzey seviyede bulunmuştur. Analizler sonucunda Mühendislik Etiği Ölçeğinin yap1 geçerliliğinin uygun olduğu ortaya konulmuştur.

Doğrulayıcı Faktör Analizi (DFA), verinin temelindeki yapıyı değerlendiren açıklayıcı faktör analizinin (AFA) uzantısıdır (Öksüz ve Malhan, 2005; Lee, 2007). AFA, hipotez kurmaya yönelik bilgi edinilmesini sağlamaya çalışırken; DFA, belirlenen bu faktörler arasında yeterli düzeyde ilişkinin olup olmadığını, hangi değişkenlerin hangi faktörlerle ilişkili olduğunu, faktörlerin birbirlerinden bağımsız olup olmadığını, faktörlerin modeli açıklamakta yeterli olup olmadığını sınamak için kullanılır (Özdamar, 2004). RMSEA için 0 değeri mükemmel uyumu, 0.050'nin altındaki değerler iyi uyum, 0.080'in 
altındaki değerler makul uyum, 0.080 ile 0.10 arasındaki değerler orta düzeyde bir uyum göstergesi iken, 0.10'un üstündeki değerler kabul edilir değildir (Akgül, 2005; Büyüköztürk, 2015; Erkorkmaz ve ark., 2012). İyi bir uyum için RMSEA değeri ile birlikte RMR değerinin 0.10'dan küçük olması ve CFI değerinin 0.90 'a eşit ya da üstünde olması gerekir (Şimşek, 2007; Harrington, 2009; Büyüköztürk, 2015; Erkorkmaz ve ark., 2012; Akgül, 2005). GFI değerinin 0.90'a eşit ya da üstünde olması uyumun olduğunu gösterir (Şimşek, 2007; Harrington, 2009; Büyüköztürk, 2015; Erkorkmaz ve ark., 2012; Akgül, 2005). Ancak, Lin (2007)'in yapmış olduğu çalışmada 0.80 'e eşit veya üstünde olması da kabul edilebilir değer olarak alınmıştır. NFI değerleri 0.90'in üzerindeyken, çok uygun olduğunu gösterir. Garson, (t.y), bazı araştırmacıların daha esnek bir şekilde limit olarak 0.80 değer aldığını belirtir.

Mühendislik Etiği Ölçeğinin uyum indeksleri RMSE 0.071, GFI 0.80, CFI 0.93, RMR 0.064, NFI 0.81, TLI 0.82 olarak saptanmıştır. Doğrulayıcı faktör analizleri sonucunda Mühendislik Etiğgi Ölçeğinin alt boyutlarındaki faktör yüklerinin tamamının 0.40'dan büyük olduğu, CFI, IFI, TLI'nın $>0.90$, NFI, GFI'nın >0.80 ve RMSEA, RMR'nin $<0.08$ 'den olduğu saptanmıştır (Tablo 7).

\section{Sonuç}

Türkiye'de Harita ve Kadastro Mühendisleri Odasına üye olup mesleğini aktif olarak icra eden meslek insanları üzerinde "Etik Kuralların Önemsendiği Mesleki Bir Yaşamın Toplum Sağlığ Bakımından Önemi” konusunda etik duyarlılı̆̆ı ölçmek amacıyla yapılan bu çalışmada;

- Mühendislik Etiği Ölçeğinin, Türkiye'de harita mühendisliği mesleğini icra edenler için kullanılabilecek geçerli bir ölçek olduğu,

- Mühendislik Etiği Ölçeğinin, Türkiye'de harita mühendisliği mesleğini icra edenler için kullanılabilecek güvenilir bir ölçek olduğu,

- Mühendislik Etiği Ölçeğinin, mesleki toplumsal duyarlılıkların ölçülmesi ve mesleki davranış olgunluğunun geliştirilmesi amaçlı çalışma yapmak isteyen uzmanlar tarafindan kullanılabileceği düşünülmektedir. 


\section{Kaynaklar}

Ahadzie DK, Proverbs DG, Olomolaiye PO (2008). Critical success criteria formass house building projects in developing countries, International Journal of Project Management 26: $675-687$.

Akgül A (2005). Tıbbi araştırmalarda istatistiksel analiz teknikleri - SPSS uygulamaları, 3. Baskl, Ankara.

Boatright J (2003). Ethics and the conduct of business, $4^{\text {th }}$ Edition, Upper Saddle River, New Jersey.

Büyüköztürk Ş (2015). Sosyal bilimler için veri analizi el kitabı araştırma deseni SPSS uygulamaları ve yorum, 22.Bask1, Pegem Akademi Yayılarl, Ankara.

Devellis R (2012). Scale development theory and applications, Sage Publications, New York.

Ercan İ, Kan İ (2004). Ölçeklerde güvenirlik ve geçerlik, Uludă̆ Üniversitesi Tıp Fakültesi Dergisi 30(3): 211-216.

Ergin DE (1995). Ölçeklerde geçerlik ve güvenirlilik, M.Ü. A.E.F. Eğitim Bilimleri Dergisi 7: $125-148$.

Erkorkmaz Ü, Etikan İ, Demir O, Özdamar K, Sanisoğlu SY (2012). Doğrulayıcı faktör analizi ve uyum indeksleri, Türkiye Klinikleri J Med Sci 33(1): 210-223.

Garson GD (t.y.). Quantitative research in public administration. http://faculty.chass.ncsu.edu/garson/PA765/index.htm (Erişim Tarihi:11.04.2020).

Ghosh S, Jintanapakanont J (2004). Identifying and assessing the critical risk factors in an underground rail Project in Thailand: a factor analysis approach, International Journal of Project Management 22: 633-643.

Harrington D (2009). Confirmatory factor analysis, Oxford University Press, New York.

İşgüden B, Çabuk A (2006). Meslek etiği ve meslek etiğinin meslek yaşamı üzerindeki etkileri, Balıkesir Üniversitesi Sosyal Bilimler Enstitüsü Dergisi 9(16): 59-86.

Johnson RB, Christensen LB (2014). Educational research quantitative, qualitative, and mixed approaches, $5^{\text {th }}$ Edition, Sage Publications, New York.

Köklü N, Büyüköztürk Ş, Bökeoğlu ÖÇ (2006). Sosyal bilimler için istatistik, Pegem Yayıncılık, Ankara.

Lee SY (2007). Structural equation modeling: a bayesian approach, Wiley Press, New York.

Lin HF (2007). Predict consumer intentions to shop online: an empirical test of competing theories, Electronic Commerce Research and Applications 6(4): 432-442.

Maclagan D (1995). The hidden cost of outsider art: ethical and psychological issues, Raw Vision 12: 30-37.

Öksüz E, Malhan S (2005). Reliability and validity of the Turkish version of the Florida sexual history questionnaire, Turkiye Klinikleri J Med Sci 25(2): 204-212.

Özdamar K (2004). Tabloların oluşturulması, güvenirlik ve soru analizi, paket programlarla istatistiksel veri analizi-1. 5. Baskı, Kaan Kitabevi, Eskişehir.

Scherer RF (1988). Dimensionality of coping: factor stability using the ways of coping quesionnaire, Psychological Report 62: 760-770. 
Şencan H (2005). Sosyal ve davranışsal ölçümlerde güvenirlik ve geçerlik, Seçkin Yayıncılık, Ankara.

Şaban M, Atalay B (2005). Yönetim muhasebecileri açısından etik ve etik davranışın önemi, Muhasebe ve Denetime Bakış Dergisi 5(16): 49-60.

Şimşek ÖF (2007). Yapısal eşitlik modellemesine giriş temel ilkeler ve LISREL uygulamaları, Ekinoks Yayınları, Ankara.

T.C. Milli Eğitim Bakanlığı (2006). Meslek etiği, MEGEP(Mesleki Eğitim ve Öğretim Sisteminin Güçlendirilmesi Projesi), Ankara.

Tansal S (2002). Etik değerlere evrensel yaklaşım, Executive Excellence Dergisi 64: 10-11.

Tavşancıl E (2019). Tutumların ölçülmesi ve SPSS ile veri analizi, 6. Baskı, Nobel Yayınları, Ankara.

Tezbaşaran, A (1997). Likert tipi ölçek geliştirme kılavuzu, Türk Psikologlar Derneği Yayınları, Ankara. 